\title{
KONDISI SOSIAL EKONOMI KOMUNITAS PEMULUNG DI TEMPAT PEMBUANGAN AKHIR (TPA) MUARA FAJAR RUMBAI PEKANBARU: FENOMENA DAN SOLUSI
}

\author{
Asliati \\ Fakultas Dakwah dan Ilmu Komunikasi UIN Suska Riau \\ asliati@,uin-suska.ac.id
}

\begin{abstract}
Abstrak
Salah satu masalah sosial yang ada di tengah masyarakat adalah masalab kemiskinan. Adapun kemiskinan tidak akan bisa di berantas kalau hanya sebatas di jadikan bahan diskusi. Untuk itu perlu langkah konkrit untuk mengatasi kemiskinan tersebut. Karya tulisan ini hasil penelitian penulis di mana berusaha mengemukakan fakta sesuai fenomena yang ada dilapangan melalui hasil observasi dan wawancara dengan pemulung dan sumber terkait. Dalam tulisan ini penulis berupaya mengungkap fenomena pemulung di TPA Muara Fajar dan mengadakan analisis selanjutnya ditawarkan solusi. Tinjauan teori dikemukakan tentang seluk beluk pemulung dan konsep kemiskinan. Sangat banyak tinjauan definisi pemulung namun dapat disimpulkan pemulung adalah seorang atau sekelompok manusia yang penghidupannya diperoleh dari mencari atau mengumpulkan barang-barang bekas yang telah terbuang di tempat pembuangan sampah sebagai barang bekas. Sedangkan kemiskinan disimpulkan adalah kurangnya pendapatan untuk memenubi kebutuhan bidup yang pokok. Setelah data didapatkan dan dilakukan analisis maka diperoleh kesimpulan bahwa kondisi social ekonomi komunitas pemulung di TPA Muara Fajar Rumbai Pekanbaru adalah berada pada level memprihatinkan, hal ini berdasarkan tinjauan terhadap beberapa faktor berikut Faktor Pendidikan rata-rata pemulung hanya menamatkan Sekolah Dasar (SD). Faktor Pekerjaan bahwa pemulung tidak mempunyai pilihan lain karena keterbatasan akses kepada pekerjaan pada sektor formal. Faketor Penghasilan bahwa rata-rata hasil yang didapat dari pekerjaan sebagai pemulung hanya mencukupi kebutuhan pangan sehari-hari dan sangat kesulitan ketika ingin memenubi kebutuban sandang dan papan. Faktor Perumahan kebanyakan pemulung yang ada di TP A Muara Fajar belum memiliki rumah sendiri dan hidup dalam rumah kontrakan yang sempit dengan jumlah keluarga tergolong besar dengan jumlah anak 3 sampai 6 orang. Faktor Pelayanan kesehatan bahwa pemulung cenderung ketika sakit tidak tidak buru-buru berobat ke Rumah Sakit atau ke Puskesmas dengan alasan keterbatasan biaya dan apabila berobat memakai kartu berobat gratis pemulung tidak mendapatkean pelayanan yang semestinya. Adapun solusi yang ditawarkan adalah memberikan pelatihan life skill dengan harapan memperoleh penghidupan yang lebih baik.
\end{abstract}

Kata Kunci: isi, format, artikel.

\section{PENDAHULUAN}

Masalah kemiskinan di Indonesia merupakan masalah yang yang tidak habishabisnya di bicarakan. Berbagai program pemerintah digelontorkan dalam usaha pengentasan kemiskinan. Namun program tersebut yang notabene memakan anggaran Negara yang tidak sedikit tetapi tidak mencapai hasil yang maksimal. Pada tahun 2012 APBN mengeluarkan anggaran 1.548 Trilyun untuk pengentasan kemiskinan namun anggaran tersebut cenderung tidak tepat sasaran sehingga angka kemiskinan berkurang hanya berkisar antara 1-1.5 juta jiwa pertahun.

Pada saat ini dengan besarnya jumlah penduduk di Indonesia tentu saja memerlukan lapangan pekerjaan yang banyak. Pemerintah harus berpikir keras supaya bagaimana penduduk miskin bisa diberdayakan. Di perkotaan misalnya dengan kuantitas jumlah penduduk lebih padat dibandingkan dengan pedesaan muncul masalah yang sangat krusial seperti sampah. Sampah sebagai hasil sampingan dari berbagai aktifitas dalam kehidupan manusia maupun sebagai hasil dari proses alamiah, seringkali menimbulkan permasalahan terutama di perkotaan. Semakin berkembang suatu kota akibat pertambahan jumlah penduduk serta peningkatan aktifitas hidupnya menyebabkan masalah yang ditimbulkan oleh sampah semakin besar dan kompleks.

Volume sampah yang semakin meningkat baik jumlah timbunan sampah maupun jenisnya, serta kurangnya proses pengelolaan sampah yang memenuhi syarat kesehatan, merupakan masalah yang harus ditanggulangi secara benar dan terpadu sehingga memerlukan kerjasama dari berbagai pihak. Dalam hal ini pemerintah setempat mencari solusi bagaimana supaya sampah tidak menimbulkan dampak bagi 
lingkungan maka dibuatlah Tempat Pembuangan Akhir (TPA).

Awalnya TPA dibangun sudah tentu bertujuan untuk menampung segala jenis sampah. Seharusnya sampah-sampah tersebut dikelola sesuai dengan teori-teori yang ada. Namun kenyataan di lapangan bahwa pengelolaan sampah tidak berjalan sebagaimana mestinya sehingga muncul masalah baru yakni terjadinya penumpukan sampah. Ditengah timbunan sampah yang menggunung terlihat fenomena yang tak biasa. Tak jarang masyarakat memanfaatkan tumpukan sampah-sampah tersebut sebagai tempat untuk mencari nafkah.

Permasalahan sampah di Pekanbaru berasal dari buangan sampah pemukiman, sampah pasar, sampah pertokoan, sampah dari lembaga pendidikan, perkantoran, sarana atau fasilitas umum dan lain sebagainya. Salah satu TPA yang terdapat di Kota Pekanbaru adalah TPA Muara Fajar yang berlokasi di jalan Yos Sudarso Rumbai. Keberadaan TPA ini dimanfaatkan oleh komunitas para pemulung dalam mencari rezeki untuk memenuhi kebutuhan sehari-hari. Kehidupan keseharian komunitas pemulung di TPA Muara Fajar Rumbai Pekanbaru tidak jauh berbeda dengan komunitas pemulung di TPA lainnya di Indonesia. Dari jam kerja yang panjang dan tak tentu ( dari pagi hingga malam ), gangguan kesehatan yang menghantui para pemulung sampai masalah kondisi lingkungan TPA yang sewaktu-waktu dapat mengancam nyawa mereka. Semua itu seakan tidak dapat menghalangi mereka untuk mengais sampah demi menghasilkan rupiah untuk kelangsungan kehidupan keluarganya di tengah desakan kebutuhan ekonomi yang semakin tinggi.

\section{HASIL DAN PEMBAHASAN}

\section{Pengertian Sosial Ekonomi}

Pengertian sosial ekonomi jarang dibahas secara bersamaan. Pengertian sosial dan pengertian ekonomi sering dibahas secara terpisah. Pengertian sosial dalam ilmu sosial menunjuk pada objeknya yaitu masyarakat. Sedangkan pada departemen sosial menunjukkan pada kegiatan yang ditunjukkan pada untuk mengatasi persoalan yang dihadapi oleh masyarakat dalam bidang kesejahteraan yang ruang lingkupnya pekerjaan dan kesejahteran sosial.

Dalam kamus besar bahasa Indonesia, kata sosial berarti segala sesuatu yang berkenaan dengan masyarakat (KBBI, 1996 : 958). Sedangkan dalam konsep sosiologi, manusia sering disebut sebagai makhluk sosial yang artinya manusia tidak dapat hidup wajar tanpa adanya bantuan orang lain di sekitarnya. Sehingga kata sosial sering diartikan sebagai halhal yang berkenaan dengan masyarakat.

Sementara istilah ekonomi sendiri berasal dari kata Yunani yaitu "oikos" yang berarti keluarga atau rumah tangga dan "nomos" yaitu peraturan, aturan, hukum. Maka secara garis besar ekonomi diartikan sebagai aturan rumah tangga atau manajemen rumah tangga.

Dalam Kamus Besar Bahasa Indonesia, ekonomi berarti ilmu yang membahas mengenai asas-asas produksi, distribusi dan pemakaian barang-barang serta kekayaan (seperti keuangan, perindustrian dan perdagangan) (KBBI, 1996 : 251).

Berdasarkan beberapa pengertian diatas, maka dapat disimpulkan bahwa sosial ekonomi adalah segala sesuatu yang berkaitan dengan pemenuhan kebutuhan masyarakat, antara lain, sandang, pangan, perumahan, pendidkkan, kesehatan dan lain-lain. Pemenuhan kebutuhan tersebut berkaitan dengan penghasilan.

Menurut Melly G Tan bahwa kedudukan sosial ekonomi mencakup 3 (tiga) faktor yaitu pekerjaan, pendidikan, dan penghasilan. Berdasarkan pendapat ini masyarakat tersebut dapat digolongkan kedalam kedudukan sosial ekonomi rendah, sedang dan tinggi (Konntjoroningrat, 1981 : 35). Pendapat diatas didukung oleh Mc. Mahbud UI Hag dari Bank Dunia bersama dengan James Grant dari Overseas Development Council mengatakan bahwa kehidupan sosial ekonomi dititikberatkan pada pelayanan kesehatan, pendidikan, perumahan dan air yanag sehat yang didukung oleh pekerjaan yang layak (Melly dalam Susanto, 1984). 


\section{Pengertian Komunitas}

Komunitas adalah sebuah kelompok soaial dari beberapa organisme yang berbagi lingkungan, umumnya memiliki ketertarikan dan habitat yang sama. Dalam komunitas manusia, individu-individu didalamnya dapat memiliki maksud, kepercayaan, sumber daya, preferensi, kebutuhan, resiko dan sejumlah kondisi lain yang serupa. Komunitas berasal dari bahasa Latin communitas yang berarti "kesamaan", kemudian dapat diturunkan dari communis yang berarti "sama, publik, dibagi oleh semua atau banyak". (Wenger, 2002 : 4). Menurut Crow dan Allan, komunitas dapat terbagi menjadi 3 komponen : 1. Berdasarkan lokasi atau tempat wilayah atau tempat sebuah komunitas dapat dilihat sebagai tempat dimana sekumpulan orang mempunyai sesuatu yang sama secara geografis.

2. Berdasarkan minat, sekelompok orang yang mendirikan suatu komunitas karena mempunyai ketertarikan dan minat yang sama misalnya agama, pekerjaan, suku, ras, maupun berdasarkan kelainan seksual. 3. Berdasarkan komuni-komuni dapat berarti ide dasar yang dapat mendukung komunitas itu sendiri.

\section{Pemulung}

Pemulung adalah seorang atau sekelompok manusia yang penghidupannya diperoleh dari mencari atau mengumpulkan barang-barang bekas yang telah terbuang di tempat pembuangan sampah sebagai barang bekas (Pramuwito, 1992 dalam Ameriani, 2006). Pemulung adalah mereka yang bekerja mendayagunakan barang-barang yang diperoleh dari sampah kota, tidak termasuk rumah tangga dan pembantu yang memilah-milah koran kemudian dijual bilamana waktunya tepat dan pengusaha besar yang membeli dan menjual barang-barang bekas ( Birkbeck, 1976).

Pemulung sampah merupakan komponen yang tampak dalam suatu sistem, ditandai dengan karung yang dibawa ataupun gerobak kecil. Pemulung tidak sama dengan pengangguran yang menggunakan waktu sambilan untuk mengumpulkan carikan kertas. Banyak orang yang terjun menjadi pemulung dalam tempo yang singkat. Pemulung bukanlah pekerja Dinas Kebersihan Kotamadya (Birkbeck, 1976).
Dinas Kebersihan DKI Jakarta Tahun 1990 (Simanjuntak, 2002) mendefinisikan pemulung sebagai :

a. Pemulung merupakan bagian masyarakat atau WNI yang mempunyai hak dan kewajiban yang sama sesuai dengan UUD 1945.

b. Pemulung adalah pelaku penting dalam proses daur ulang (recycling) sampah sebagai salah satu bagian dalam penanganan sampah perkotaan maupun pedesaan.

c. Pemulung adalah salah satu pemelihara lingkungan hidup yang menyerap sebagian sampah untuk dapat diolah menjadi barang yang berguna bagi masyarakat.

d. Pemulung adalah orang yang bekerja memunguti dan mengumpulkan sampah dan memanfaatkan sampah-sampah tersebut untuk menambah penghasilan mereka.

Pemulung dikategorikan menjadi dua, yaitu pemulung jalanan atau pemulung keliling, yaitu pemulung yang hidup bebas dijalanan dan pemulung tetap, ayitu pemulung yang mempunyai rumah (bedengan) yang berada disekitar TPA atau sekitar lapak (tempat menjual barang hasil pulungan pemulung) (Twikromo, 1999).

Usia pemulung sampah beraneka ragam, mulai dari anak-anak yang secara substansial menganggur dipaksa untuk membantu ekonomi rumah tangga hingga usia diatas 40 tahunan. Lebih dari separuh pemulung tidak mengecap pendidikan SLTP, mereka memang sempat sekolah namun hanya sekedar dapat baca tulis.

Gambaran tepat tentang pemulung tidak diperoleh secara pasti. Hal ini karena lemahnya perhitungan statistik karena para peneliti mengalami kesulitan untuk menghitung mereka. Jumlah pemulung tidak pernah konstan, tetapi mengalami pasang surut. Pekerjaan pemulung itu mudah dan tidak memerlukan modal dan ketrampilan tinggi sehingga banyak orang yang terjun menjadi pemulung dalam tempo yang singkat (Lumingkewas, 1997).

Alasan menjadi pemulung sangat beragam, namun alasan yang paling banyak dikemukakan adalah profesi ini tidak memerlukan persyaratan tertentu, seperti pendidikan, ketrampilan dan modal, tidak ada alternatif pekerjaan lain, pekerjaan ini mudah dilakukan dan ada relasi yang sudah bekerja lebih dulu di kota. Alasan berikutnya, pekerjaan memulung memiliki resiko 
rendah karena hanya bermodalkan tenaga (tidak mengeluarkan modal seperti kita bercocok tanam) maka pemulung sudah dapat merasakan hasilnya secara langsung asalkan pemulung tersebut rajin bekerja (Ameriani, 2006).

Pemulung selalu diidentikkan oleh kaum miskin, namun penelitian di Cali Colombia memaparkan bahwa pemulung merupakan suatu pekerjaan dan pendapatan mereka jauh lebih besar dari buruh pabrik (Birkbeck, 1976). Tetapi tetap saja walaupun penghasilan lebih tinggi dari buruh pabrik namun mereka dalam situasi yang berbeda. Akan tetapi tempak jelas bahwa orang akan keluar-masuk dari dan ke pekerjaannya sebagai pemulung dan pekerjaan tersebut lebih berfungsi sebagai penyangga hidup, yang berlainan dengan konsep kemiskinan absolut yang dikemukakan oleh Keith Hart tahun 1985.

Ada hal menarik dari hasil pengamatan yang dilakukan di Cali, Colombia mengenai pemulung yaitu suatu ungkapan bahwa pemulung adalah cerminan dari kemiskinan dan bukan penyebab kemiskinan (Birkbeck, 1976). Seperti yang kita ketahui bahwa pemulung adalah sekelompok orang yang terpaksa melakukan pekerjaan memulung barang bekas karena tidak ada pekerjaan yang dapat mereka lakukan. Dan terkadang masyarakat dan pemerintah tidak menyadarinya bahwa pemulung merupakan suatu profesi (pekerjaan). Hal ini juga sesuai dengan konsep kerja menurut Departemen Pendidikan dan Kebudayaan tahun 1991 bahwa kerja adalah kegiatan melakukan sesuatu. Pemulung jelas melakukan sesuatu yaitu mengumpulkan barang bekas. Oleh karena itu, pemulung bukanlah pengangguran yang tidak mempunyai kegiatan. (Ameriani, 2006)

Dalam tulisan Crish Birkbeck menjelaskan bahwa pemulung bergantung pada pabrik. Namun, pernyataan itu dibantah oleh Suparlan (1981) yang menyatakan bahwa pemulung merupakan armada murah buat pabrik. Pemulung yang selalu mensuplai kebutuhan pabrik namun ia dibayar dengan sangat rendah sekali. Pemulung bukanlah karyawan pabrik, namun mereka bagian dari sistem industri tersebut. Mereka bekerja untuk pabrik tetapi mereka tidak memperoleh gaji dari pabrik. Oleh karena itu kemiskinan mereka terletak pada hubungannya dengan industri.(Crish Birkbeck: 1976)
Pemulung merupakan ujung tombak bagi para pedagang sampah daur ulang. Pemulung tidak independen menentukan harga, bahkan untuk memilih pembeli yang lebih baik pun tidak bisa. Pabrik yang menentuka harga untuk harga barang bekas, hal itu yang mendasari pembatasan aliran pendapatan ke pemulung sehingga para pemulung perlu menyatu dengan rekannya dan berserikat kerja serta menuntut harga yang lebih tinggi atau meningkatkan produktivitasnya (Santoso, 2000). Dalam hal ini bukan menambah jam kerja mencari pulungan tetapi lebih ke ketrampilan pemulung.

Cara pemulung jalanan dalam melaksanakan aktivitas dipandang sangat kotor, karena mereka bergulat dengan sampah setiap harinya. Walaupun jumlah penghasilan mungkin lebih tinggi dari para pegawai negeri golongan paling rendah, mereka tetap dipandang inferior. Melihat pemulung dengan segala kekurangan bukan berarti menganggap mereka sama sekali tidak memiliki profesi (Twikromo, 1999).

Pemulung merupakan bagian dari kejelian dan kegigihan seseorang melihat peluang dan mau bekerja keras yang didukung ekonomi kota yang memberikan kemungkinan lebih besar bagi para anggota rumah tangga miskin untuk mengakses peluang kerja disekitar informal kota. Pendapatan pemulung tergantung dari banyaknya hasil pulungannya. Jadi setiap pemulung mempunyai pendapatan yang berbeda tergantung seberapa gigih pemulung berusaha (Twikromo, 1999).

Bagi pemulung sangat sulit untuk dapat menyimpan uang. Kebanyakan diantara mereka terlibat hutang. Oleh karena itu, orang-orang yang memberikan pinjaman kepada pemulung dapat menjadi tokoh yang berpengaruh dan berkuasa. Hubungan diantara pemulung dan bidang uang dengan para tetangga dapat berubah menjadi suatu ikatan hubungan pelindung dengan yang dilindungi (patron client relationship) (Mangiang et al. 1979).

Pemulung menjadi miskin bukanlah karena mereka tidak bekerja atau kurang jumlah kerjanya. Tetapi mereka miskin karena faktorfaktor struktural yang menghalangi pemulung untuk memperoleh kelebihan keuntungan dari kegiatan pulungan yang mereka lakukan dan untuk pemulung mengakumulasikan uang. Selain itu, karena pemulung tidak dapat 
mendayagunakan kesempatan yang ada karena kesempatan tersebut dikuassai oleh satu pihak dalam hal ini lapak ataupun bandar-bandar (Mangiang: 1979).

Pada dasarnya, banyak batasan dihadapi oleh para pemulung yang hidup di daerah perkotaan. Banyak peraturan dan common sense masyarakat kota yang mendukung pembangunan kota telah membuat pemulung hidup di bawah tekanan-tekanan sosial-budaya. Walaupun demikian, beberapa di antara mereka masih dapat menemukan kebahagiaan dalam kehidupannya (Twikromo, 1999). Sebagian besar pemulung masih menyadari keberadaannya dalam masyarakat kota.

Pemulung menerima sikap-sikap diskriminatif masyarakat kota seperti tidak diperbolehkan masuk ke daerah tertentu. Banyaknya tulisan "pemulung dilarang masuk" di sudut-sudut perkampungan/perumahan ataupun perkantoran juga menandakan keberadaan mereka belum sepenuhnya dihargai masyarakat. Larangan-larangan itu resistensi yang menyakitkan bagi kaum pinggiran seperi mereka (Twikroo, 1999).

Pemerintah cenderung menggunakan langkah penekanan dari pada memberi kelonggaran terhadap keberadaan orang jalanan termasuk pemulung. Dengan demikian, pemulung akan terperangkap ke dalam suatu pengucilan sosial dari masyarakat kota pada umumnya. Masalah keindahan dan tata kota kerap menjadi alasan pemerintah untuk menata kawasan kumuh. Padahal tidak sedikit juga pemulung menata tempat yang dianggap kumuh menjadi lebih baik (Twikromo, 1999).

Pemulung tidak pernah terlibat atau dilibatkan dalam proses perkembangan kota. Mereka juga jarang disentuh oleh dampak positif perkembangan kota. Kepentingan-kepentingan mereka tidak pernah terwakili atau cenderung diabaikan oleh pemerintah kota. Pengabaian ini dimaksudkan untuk menekan peningkatan jumlah orang jalanan di daerah perkotaan (Twikromo, 1999).

Pemulung mungkin dapat membentuk masyarakat yang lebih stabil tanpa bantuan pemerintah dan mengaitkan diri sendiri ke lapangan pekerjaan yang stabil. Gambaran ini mengubah kesan yang sering melukiskan pemulung sebagai golongan yang tak layak bertempat tinggal dan merupakan benalu di kota. Padahal pemulung mempunyai kontribusi yang besar pada lingkungan kota (Suparlan, 1981).

\section{Pengertian Kemiskinan}

Sejauh ini studi tentang kemiskinan sudah sangat banyak dilakukan, namun pertanyaan tentang apa itu kemiskinan dan faktor apa saja yang menyebabkan kemiskinan itu sulit diberantas masih terdapat pendapat yang simpang siur. Berbeda pendapat para ahli dalam masalah ini. Levitan (1980) misalnya mendefinisikan kemiskinan sebagai kekurangan barang-barang dan pelayanan-pelayanan yang dibutuhkan untuk mencapai suatu standar hidup yang layak. Schiller (1979), mengemukakan bahwa kemiskinan adalah ketidaksanggupan untuk mendapatkan barang-barang dan pelayanan-pelayanan yang memadai untuk memenuhi kehidupan sosial yang terbatas. Selanjutnya dengan nada yang sama Emil Salim mendefinisikan kemiskinan sabagai kurangnya pendapatan untuk memenuhi kebutuhan hidup yang pokok (Ala: 1981).

Banyak bukti menunjukkan bahwa yang disebut orang atau keluarga miskin pada umumnya selalu lemah dalam kemampuan berusaha dan terbatas aksesnya kepada kegitan ekonomi sehingga seringkali makin tertinggal jauh dari masyarakat lain yang memiliki potensi labih tinggi. Wignjosoebroto dkk (1992) melakukan studi tentang kehidupan masyarakat rentan di kotamadya Surabaya dan menemukan bahwa seseorang atau sebuah keluarga yang dijejas kemiskinan, mereka umumnya tidaklah banyak berdaya, ruang geraknya serba terbatas, dan cenderung kesulitan untuk terserap dalam sektor-sektor yang memungkinkan mereka dapat mengembangkan usahanya. Jangankan untuk mengembangkan diri menuju ke taraf sejahtera, sedangkan untuk bertahan menegakkan hidup fisknya pada taraf yang subsistem saja bagi keluarga miskin hampir merupakan hal yang mustahil bila tidak ditopang oleh jaringan dan pranata sosial dilingkungan sekitarnya.

Definisi yang lebih lengkap tentang kemiskinan dikemukakan oleh John Friedman (1979), bahwa kemiskinan adalah ketidaksamaan untuk mengakumulasi basis kekuasaan sosial. Sementara yang dimaksud basis kekuasaan sosial itu menurut Friedman 
meliputi ; Pertama, modal produktif atas asset, misalnya tanah perumahan, peralatan dan kesehatan. Kedua, sumber keuangan seperti income dan kredit yang memadai. Ketiga, organisasi sosial dan politik yang dapat digunakan unutk mencapai kepentingan bersama, seperti koperasi. Keempat, network atau jaringan sosial unutk memperoleh pekerjaan, barang-barang, pengetahuan dan keterampilan yang memadai. Kelima, informasiinformasi yang berguna untuk kehidupan.( John Friedman: 1979)

Ada beberapa penyebab kemiskinan sebagai berikut :

1. Menurut akar penyebab yang melatarbelakangi, secara teoritis dapat dibedakan menjadi dua. Pertama, kemiskinan alamiah, yakni kemiskinan yang timbul sebagai akibat sumber-sumber daya yang langka jumlahnya atau karena tingkat perkembangan teknologi yang sangat rendah. Artinya faktor-faktor yang menyebabkan suatu masyarakat menjad miskin adalah secara alami memang ada, dan bukan bahwa akan ada kelompok atau individu di dalam masyarakat tersebut akan diperlunak atau dieliminasi oleh adanya pranata-pranata tradisional, seperti pola hubungan patronclient, jiwa gotong royong dan sejenisnya yang fungsional untuk meredam kemungkinan timbulnya kecemburuan sosial. Kedua, kemiskinan buatan adalah kemiskinan yang terjadi karena struktur sosial yang ada membuat anggota atau kelompok masyarakat tidak menguasai sarana ekonomi dan fasilitasfasilitas secara merata. Dengan demikian sebagian anggota masyarakat tetap miskin walaupun sebenarnya umlah totsl produksi yang dihasilkan oleh masyarakat tersebut bila dibagi rata dapat membebaskan semua anggota masyarakat dari kemiskinan. Kemiskinan buatan dalam banyak hal terjadi bukan karena seorang individu atau anggota keluarga malas bekerja atau karena mereka terus menerus sakit. Berbeda dengan perspektif modernisasi yang cenderung menvonis kemiskinan bersumber dari lemahnya etos kerja, tidak dimilikinya etika wirausaha atau karena budaya yang tidak terbiasa dengan kerja keras, kemiskinan buatan dalam perbincangan dikalangan ilmuan sosial seringkali diidentikkan dengan pengertian kemiskinan struktural.

2. Menurut Selo Sumarjan yang dimaksud dengan kemiskinan yang diderita oleh suatu golongan masyarakat, karena struktur sosial masyarakat itu tidak dapat ikut menggunakan sumber-sumber pendapatan yang sebenarnya tersedian bagi mereka. Secara teoritis, kemiskinan buatan atau kemiskinan struktural dapat diartikan sebagai suasana kemiskinan yang dialami oleh suatu masyarakat yang penyebab utamanya bersumber, oleh karena itu dapat dicari pada struktur sosial yang berlaku adalah sedemikian rupa keadaannya sehingga mereka yang termasuk kedalam golongan miskin tampak tidak berdaya untuk mengubah nasibnya dan tidak mampu memperbaiki hidupnya. Struktur sosial yang berlaku telah mengurung mereka ke dalam suasana kemiskinan secara turun-temurun selama bertahun-tahun. Sejalan dengan itu mereka hanya mungkin keluar dari penjara kemelaratan melalui suatu proses perubahan struktur yang mendasar. (Selo Sumarjan: 1980)

Definisi kemiskinan yang lebih lengkap dalam arti sesuai dengan kenyatan dan secara konseptual jelas, dikemukakan oleh Robert Chamber (1987). Menurutnya inti dari kemiskinan sebenarnya terletak pada apa yang disebut deprivation trap atau perangkap kemiskinan. Secara rinci deprivation trap terdiri dari lima unsur sebagai berikut :

1. Kemiskinan itu sendiri

2. Kelemahan fisik

3. Keterasingan atau kadar isolasi

4. Kerentanan

5. Ketidakberdayaan

Kelima unsur ini seringkali sering saling berkait satu dengan lain sehingga merupakan perangkap kemiskinan yang benar-benar berbahaya dan mematikan peluang hidup orang atau keluarga miskin. 


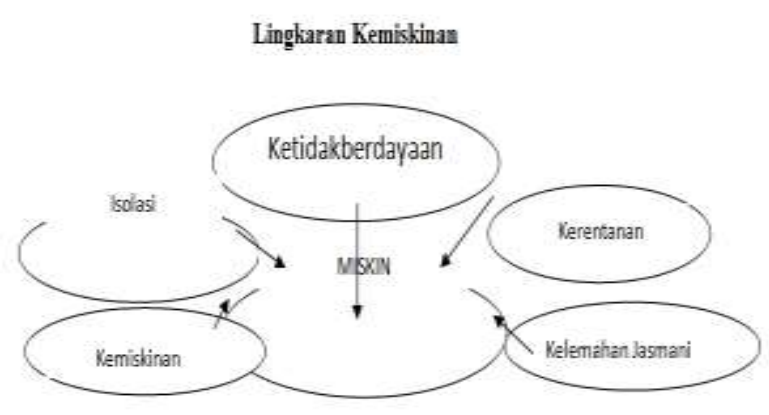

\section{Tinjauan Lokasi TPA}

Pada awal berdirinya TPA Muara Fajar proses pengolahan sampahnya dengan desain sanitary landfill, yaitu pembuangan dan penumpukan sampah kesuatu lokasi yang cekung, kemudia dilakukan pemadatan sampah tersebut dan menutupnya dengan tanah. Sistem sanitary landfill seharusnya dilakukan secara sistematis dimana setiap hari ada proses penyebaran dan pemadatan sampah pada area pengurugan dan penutupan sampah serta penutupan sel sampah harus dilakukan setiap hari. Metode ini merupakan metode standar yang dipakai secara internasional. Untuk meminimalkan potensi gangguan yang timbul, maka penutupan sampah dilakukan setiap hari. Dan untuk menerapkan sistem ini diperlukan penyediaan sarana dan prasarana yang cukup mahal.

Namun, seiring berjalannya waktu dan bertambahnya jumlah penduduk serta biaya pengelolaan yang mahal maka sistem sanitary landfill tidak lagi mampu dilakukan dan operasional TPA berubah menjadi sistem open dumping. Pada sistem terbuka atau open dumping adalah sampah dibuang begitu saja dalam sebuah tempat pembuangan akhir tanpa ada perlakuan apapun. Tidak ada penutupan tanah. Pada metode pembuangan ini juga menumpuk sampah hingga tinggi tanpa dilapisi dengan lapisan geotekstil dan saluran lindi. Tak heran bila sistem ini dinilai sangat mengganggu lingkungan.

Sistem open dumping yang diberlakukan di TPA Muara Fajar pada akhirnya juga menimbulkan dampak yang signifikan terhadap lahan TPA sendiri dan lingkungan sekitar TPA. Berdasarkan pasal 44 undang-undang No. 18 tahun 2008 tentang pengelolaan sampah, pemerintah daerah berkewajiban untuk menutup tempat pemrosesan akhir sampah yang menggunakan sistem pembuarangan terbuka (open dumping) paling lambat 5(lima) tahun sejak undang-undang tersebut diberlakukan dengan terlebih dahulu membuat perencanaan penutupan TPA. Ini berarti bahwa semua kabupaten/kota di Indonesia dilarang mengoperasikan TPA dengan sistem open dumping mulai 2013.

Di penghujung 2012 walikota Pekanbaru Firdaus, MT meninjau lokasi TPA Muara Fajar. Setelah melihat kondisi TPA yang sudah overload Walikota memerintahkan untuk segera melakukan penutupan lokasi tumpukan sampah yang lama. Sebagai gantinya diaktifkan kembali pengelolaan sampah dengan sistem sanitary landfill. Hal ini juga sesuai dengan amanat Undang-undang persampahan bahwa tidak ada alternatif lain kecuali meningkatkan pengelolaan sistemnya. Maka pada tahun 2013 TPA Muara Fajar dalam pengelolaan sampah di TPA Muara Fajar mulai memakai sistem sanitary landfill dan diharapkan mampu menetralisir limbah sampah hasil pembuangan seluruh kecamatan di kota Pekanbaru. Lokasi sanitary landfill tersebut tepat berada di bawah tumpukan sampah TPA saat ini dan memiliki luas $1 / 2$ hektar lebih.dengan sistem tersebut, limbah sampah tidak akan mengotori lingkungan dan dinilai lebih ramah lingkungan.

Hal ini diungkapkan oleh bapak Usman selaku pengawas yang di tugaskan oleh Dinas Kebersihan dan Pertamanan (DKP) Kota Pekanbaru pada wawancara penulis tanggal 29 September 2013. Namun lebih lanjut beliau mengatakan bahwa dalam rangka penilaian Adipura saat ini TPA Muara Fajar berusaha untuk membenahi kawasan TPA dengan membangun sumur lindi serta melakukan penghijauan diatas timbunan bekas urugan sampah. Program terbaru dari TPA Muara Fajar dalam rangka penilaian Adipura adalah dan memanfaatkan sampah yang ada adalah pengolahan sampah menjadi gas metan. Saat ini gas sudah produksi dan akan disalurkan ke rumah-rumah warga di sekitar TPA. Untuk sementara gas belum produksi maksimal. Apabila kapasitas jumlah sampah cukup banyak maka ke depan akan digunakan sebagai pembangkit untuk energi listrik. 
Di TPA Muara Fajar, sebagaimana TPATPA sampah lain di Indonesia ada pemandangan yang tak biasa. Di tengah tumpukan sampah yang menggunung terdapat sebanyak lebih kurang 300 pemulung menggantungkan nasib mereka pada tempat pembuangan akhir sampah.

\section{Fenomena Pemulung di TPA Muara Fajar Rumabai Pekanbaru}

Di TPA Muara Fajar terdapat tak kurang dari 300 pemulung yang terdiri dari laki-laki dan perempuan. Diantara pemulung dewasa juga terdapat pemulung anak-anak. Penulis mewawancarai pemulung yang dianggab mewakili keberadaan mereka secara umum yakni, 5 orang perempuan dewasa, 3 orang lakilaki dewasa dan 5 orang anak-anak yang terdiri dari laki-laki dan perempuan.

Berdasarkan hasil wawancara yang dilakukan maka penulis memperoleh gambaran umum tentang alasan pemulung memilih profesi sebagai pemulung tersebut antara lain, pertama, para pemulung tidak memiliki profesionalisme tertentu karena faktor rendahnya pendidikan, kedua, untuk bekerja pada sektor informal lain seperti berdagang mereka tidak punya modal.

Pemulung yang ada di TPA Muara Fajar terbagi atas beberapa kelompok berdasarkan sip jam kerja, ada yang pagi sampai siang, siang sampai sore dan sore sampai malam dan ada juga yang pagi sampai sore. Rata-rata jenis barang yang di kumpulkan oleh pemulung adalah sama seperti : kardus, logam, plastik, kaleng dan apa saja yang bernilai jual. Namun ada sebagian pemulung yang mengumpulkan sisa-sisa makanan, baik untuk dijual kepada peternak maupun untuk ternak (babi) sendiri. Para pemulung berpendapatan setiap hari berkisar antara Rp. 10.000 sampai Rp. 70.000. Namun tidak jarang mereka pulang tidak membawa uang sama sekali. Hal ini penyebabnya adalah pada saat tertentu pengepul tidak membeli barang hasil pulungan seperti plastik, dengan alasan stok masih banyak. Dalam kondisi seperti ini para pemulung merasa sangat prihatin karena kebutuhan sehari-hari tetap berjalan.

Berikut pemaparan kondisi sosial pemulung di TPA Muara Fajar Rumbai Pekanbaru.
1. Faktor Pendidikan.

Salah satu penyebab memilih pekerjaan pemulung adalah faktor pendidikan. Dalam wawancara yang penulis lakukan di lokasi penelitian dengan para pemulung terungkap fakta berikut; R. Napitupulu adalah seorang perempuan berumur 40 tahun yang merantau dari daerah asal Sumatera Utara ke Pekanbaru dan memilihi pekerjaan memulung dan sudah dijalaninya pekerjaan ini selama lebih kurang 4 tahun. Pendidikan yang pernah dijalaninya hanya sampai Sekolah Menengah Pertama (SMP) membuatnya tidak mempunyai banyak pilihan untuk memilih jenis pekerjaan. Hidup dirumah kontrakan yang kecil dengan 4 orang anak dan pekerjaan suami yang serabutan mengharuskan ibu ini bekerja untuk menunjang ekonomi keluarga dan satu-satunya pekerjaan yang bisa ia lakukan adalah menjadi pemulung. R. Napitupulu juga tidak mau bermimpi untuk mendapatkan pekerjaan lain seperti berdagang karena tidak mempunyai modal.

Tidak jauh berbeda dengan R. Napitupulu, R. Siahaan juga mengungkapkan bahwa dengan dia memilih pekerjaan menjadi pemulung sampah di TPA Muara Fajar adalah untuk membantu ekonomi keluarga. Pekerjaan lain pada sektor formal juga tak bisa didapatkan karena hanya menamatkan pendidikan SMP. Walaupun sudah mempunyai rumah sendiri yang masih gubug namun karena himpitan ekonomi pekerjaan sebagai pemulung adalah menjadi pilihan. R. Siahaan bekerja dari pagi hingga sore hari bersama suaminya disamping untuk kebutuhan hidup sehari-hari juga untuk menyekolahkan anaknya. Ia termotivasi bekerja sebagai pemulung adalah karena merasa perlu memberikan pendidikan bagi anak-anaknya dengan harapan kelak bisa mendapatkan pekerjaan yang lebih layak. Peneliti mencoba menanyakan mengapa tidak mencoba pekerjaan lain seperti pekerjaan rumah tangga (Pembantu Rumah Tanggga), R. Napitupulu berujar bahwa bekerja dengan orang lain dengan gaji bulanan tidak mencukupi kebutuhan sehari-hari, berbeda dengan bekerja sebagai pemulung tiap hari bisa membawa uang pulang asal saja mau bekerja keras.

Br. Hutagalung yang mempunyai 7 orang anak dan 3 orang ikut serta menjadi pemulung dan juga tidak ketinggalan suaminya juga sebagai 
pemulung di TPA Muara Fajar. Berlatang belakang pendidikan terakhir hanya tamatan Sekolah Dasar (SD) menurutnya tidak mungkin mendapat pekerjaan yang bagus selain menjadi seorang pemulung. Br. Hutagalung bekerja sebagai pemulung sudah berjalan 6 tahun. Aktifitas memulung dia lakoni dari pagi jam 07.00 WIB sampai sore hari jam 18.00 WIB. Perasaan jijik sudah hilang karena sampah baginya adalah uang yang dapat menghidupi keluarga. Hasil dari memulung disamping bisa memenuhi kebutuhan pangan sehari-hari juga bisa menyekolahkan sebagian anaknya. Br. Hutagalung beringinan bahwa anak-anaknya yang bisa bersekolah kelak juga bisa mendapatkan pekerjaan yang lebih baik.

Seorang anak yang berusia sekolah yakni kelas IV SD, sempat penulis wawancara bahwa dia juga melakoni pekerjaan memulung karena himpitan ekonomi keluarga dan kuatnya keinginan untuk bersekolah. Putri Marbun namanya. Putri membagi waktu antara sekolah dan bekerja. Sepulangnya sekolah setiap hari putri menuju TPA dan berbaur dengan Pemulung dewasa demi membantu oarangtuanya yang juga berprofesi sebagai pemulung di TPA tersebut. Ketika ditanyakan apakah teman-teman mengetahui pekerjaan sampingan setelah sekolah, Putri mengatakan bahwa temantemannya tahu dan Dia merasa tidak malu karena bisa bersekolah adalah impiannya.

Aritonang salah seorang pemulung lakilaki sudah menjalani pekerjaan sebagai pemulung dan merangkap ketua di kelompoknya sempat mengenyam pendidikan setingkat SMA. Berbagai pekerjaan sudah pernah dilakoni sebelum menjadi Pemulung seperti Sopir, berdagang, pekerja bangunan namun semua pekerjaan itu dia tinggalkan sebab banyak hal dan memilih bekerja sebagai pemulung menurutnya tidak mempunyai ikatan tertentu, bekerja dengan jam kerja yang diatur sendiri serta bisa menyekolahkan anak-anaknya yang berjumlah 3 orang dan sudah ada yang kuliah di perguruan tinggi. Namun Aritonang juga menyadari bekerja sebagai pemulung adalah hina menurut sebagaian orang tetapi perasaan minder sudah ia tepis jauh-jauh dan ia sudah menjalani pekerjaan ini selama lebih kurang 8 tahun.

Lebih lanjut penulis berdialog dengan salah seorang wanita muda yang kalau dilihat dari fisiknya tergolong cantik dengan usia berkisar 30 tahun. Wanita tersebut bernama N. Simamora berpendidikan tamat SMEA. Mempunyai 4 orang anak membuatnya harus bekerja dan memilih jadi pemulung karena tidak jauh berbeda dengan alasan para pemulung lain bahwa susah mendapatkan pekerjaan di sektor formal. N. Simamora juga pendatang yang tidak mempunyai KTP di Pekanbaru, inilah awalnya dia sulit mendapatkan pekerjaan di sektor formal karena pada saat Ia mencoba melamar pekerjaan syarat utama adalah KTP. Mengetahui keberadaan TPA dari teman-temannya yang sudah lebih dulu menjadi pemulung maka ia tidak berfikir panjang untuk memilih pekerjaan ini. 4 tahun sudah ia jalani pekerjaan sebagai pemulung dan tidak lagi berfikir mencari pekerjaan lain karena bekerja sebagai pemulung tidak harus memenuhi syarat-syarat lain selain adanya kemauan dan menhilangkan rasa malu. Mmuenurutnya dengan menjadi pemulung dia mungkin tidak bisa kaya namun dia bisa menyekolahkan anak-anaknya dan bisa membantu suami dalam memenuhi kebutuhan sehari-hari.

Secara umum para pemulung mengetahui dan menyadari bahwa pendidikan sangat penting dan sangat berpengaruh terhadap pekerjaan seseorang. Dengan pendidikan yang tinggi juga diharapkan bisa menjamin kelangsungan ekonomi keluarga. Ini juga dasarnya bahwa sebagian besar pemulung di TPA Muara Fajar mempunyai motivasi untuk menyekolahkan anak-anak mereka.

\section{Faktor Pekerjaan}

Para pemulung yang ada di TPA Muara Fajar memiliki alasan yang beragam untuk menjadi Pemulung. Alasan klasik yang sering mereka kemukakan adalah untuk menjadi pemulung ini karena keterbatasan keahlian (skill) dan persaingan yang keras serta keterbatasan modal. Namun tentu tidak semua alasan ini dibenarkan karena diantara pemulung tersebut ada juga yang mempunyai keahlian (skill) seperti berdagang, bertani, menjahit, sopir dan sebagainya. Hanya saja satu alasan yang juga tergolong klasik yakni tidak mempunyai modal maka pada akhirnya mereka memilih menjadi pemulung yang menurut mereka tidak dibutuhkan skill tertentu dan juga tidak membutuhkan modal. Alasan lain memilih 
pekerjaan sebagai pemulung adalah karena hasilnya jelas setiap hari dan bekerja tidak ada tekanan. Setiap hari pemulung bisa membawa pulang uang berkisar Rp. $10.000-70.000$, tentu saja ini untuk satu orang, namun apabila dalam satu keluarga ada suami, istri dan juga ada anakanak mereka bawa serta maka bisa dibayangkan hasilnya akan berkali lipat. Hanya saja kondisi ini belum bisa mencukupi segala jenis kebutuhan hidup karena tingginya nilai ekonomi dan mahalnya harga barang serta besarnya biaya sekolah di kota Pekanbaru maka para pemulung kesulitan untuk mencukupi kebutuhan setiap bulannya, maka secara umum kehidupan sosial ekonomi pemulung masih tergolong miskin.

Penulis mewawancarai beberapa pemulung diantaranya, Br. Hutagalung yang mengatakan ia memilih pekerjaan sebagai pemulung karena tidak ada lagi pekerjaan lain yang bisa dengan cepat mendapatkan hasil. Jika memulung setiap hari mendapatkan uang walaupun sedikit namun jelas asal saja ada hasil pulungan setiap harinya. Hal yang sama juga dikemukakan oleh Siahaan, dia memilih jadi pemulung karena jelas setiap hari mendapatkan uang dan bisa memenuhi kebutuhan hari itu walaupun sebenarnya jauh dari cukup. Br. Simamora berpendapat bahwa suka tidak suka pekerjaan ini harus ia jalani dan karena sulitnya mendapatkan pekerjaan maka ia menjadikan pemulung sampah sebagai profesi dan tidak lagi berfikir untuk mencari pekerjaan lain. Ibu Epi salah seorang pemulung mengatakan bahwa ia memilih pekerjaan sebagai pemulung karena himpitan ekonomi. Awalnya Ia tidak menyukai pekerjaan ini karena tidak tahan dengan bau busuk dan menyengat. Namun karena termotivasi oleh inginnya mendapat penghasilan maka lama kelamaan Ia kesampingkan perasaan jijik tersebut. Ibu sadar betul karena pendidikannya yang tidak tamat sekolah dasar maka ia tidak dapat memilih pekerjaan pada sektor formal. Lebih lanjut Ibu Epi mengatakan bahwa dengan memulung ia dapat memenuhi kebutuhan keluarga setiap hari dan bisa menyekolahkan anak-anaknya.

\section{Faktor Penghasilan}

Fenomena pemulung yang ada di TPA Muara Fajar merupakan gambaran kehidupan kaum migran yang mempunyai kualitas sumber daya yang rendah sehingga untuk tetap bertahan hidup mereka harus bekerja di sektor informal antara lain sebagai pemulung, dimana pemulung merupakan suatu pekerjaan yang memiliki tingkat penghasilan yang sangat rendah karena terkait dengan jenjang pendidikan dan keterampilan yang dimiliki.

Di TPA Muara Fajar sendiri tercatat tidak kurang $\quad 300$ orang pemulung yang menggantungkan hidupnya dari sampah TPA ini, dengan rata-rata penghasilan antara 10.000 sampai 70.000 perhari. Mereka yang berpenghasilan mencapai 70.000 perhari bekerja tak kenal lelah dari pagi hingga sore hari. Namun tak sedikit mereka juga hanya mengantongi uang 10.000 dan tak jarang juga pemulung tidak membawa uang sama sekali pulang kerumah. Hal ini terjadi akibat pengepul tidak mengirim barang ke Medan dengan alasan persediaan di pabrik masih menumpuk. Maka kalau hal ini terjadi pemulung harus berusaha mencari pinjaman uang kepada pengepul, dan tentu saja keesokan harinya uang yang didapat sudah tentu juga untuk menutup hutang yang ada.

R. Napitupulu misalnya, pria asal Sumatera Utara ini mengaku terkadang tidak membawa uang sepeserpun pulang kerumah dikarenakan pengepul tidak membeli barang pada saat-saat tertentu. Pria yang mempunyai anak 4 0rang ini mengaku sangat kesusahan kalau hal ini terjadi karena anak-anak butuh makan. Belum lagi Napitupulu mengatakan bahwa penghasilan yang didapat setiap harinya tergantung kerja keras dan kesehatan badan. Kalau badan lagi tidak fit maka menuturnya penghasilan berkurang dan bahkan tidak bekerja memulung pada hari itu.

Pria yang tidak tamat Sekolah Dasar ini mengaku menjadi pemulung memang bukan tujuan hidupnya, namun karena lapangan pekerjaan yang sedikit untuk tingkat pendidikan yang dia miliki maka mau tidak mau pekerjaan memulung harus dijalani dan bisa menutup kebutuhan sehari-hari walaupun jauh dari cukup. Lebih lanjut Napitupulu mengatakan bahwa sewaktu-waaktu ada pekerjaan yang lebih baik maka dia siap meninggalkan profesi sebagai pemulung.

Hal yang sama juga diungkapkan oleh seorang ibu yakni Simamora, wanita yang mengaku berumur 48 tahun ini bekerja sebagai pemulung karena melihat ada penghasilan yang didapat tiap hari walaupun jauh dari yang diinginkan. Simamora berangkat dari rumah jam 
6 pagi sampai pulang ke rumah jam 6 sore. Dalam memulung Dia bukan saja mengumpulkan jenis sampah seperti plastik, karton, dan sejenisnya tapi juga mengumpulkan sisa-sisa makanan untuk ternak sendiri (babi) dan selebihnya juga dijual kepada tetangga yang membutuhkan. Simamora mengaku bisa mengantongi uang seharinya mencapai Rp. 40.000 hingga 70.000 namun penghasilan ini belum memadai karena besarnya kebutuhan sehari-hari dan perbulannya. Wanita ini mengaku mempunyai anak 4 0rang, yang paling besar sudah kelas 1 Sekolah Menengah Pertama (SMP) dan satu lagi Sekolah Dasar (SD) dan yang lainnya belum bersekolah. Wanita ini juga mengaku bahwa sekeras apapun usaha yang ia lakukan pagi hingga sore harinya tidak merubah kehidupannya yang saat ini juga dia masih mengontrak rumah. Namun ia tetap menjalani pekerjaan ini disamping penghasilannya jelas perhari, bekerja tidak ada paksaan dan yang membuat alasan kuat adalah tidak bisanya ia memasuki lini pekerjaan formal. Pernah ia mencoba bekerja sebagai pembantu rumah tangga namun karena uang yang ditunggu perbulannya tidak mencukupi akhirnya ia menjalani pekerjaan sebagai pemulung yang sudah ia jalani hingga saat ini lebih kurang 5 tahun.

Pengalaman sebagai pemulung juga dirasakan oleh seorang anak yang menjadi pemulung karena mengikuti orang tuanya. Sempat bersekolah namun karena keterbatasan biaya akhirnya berhenti dan ikut orang tua memulung. Tomas nama anak ini. Ia memulung karena disamping ingin membantu orang tua juga bisa mendapatkan sekedar uang jajan. Penghasilan yang didapat tidak seberapa dibanding para orang tua namun cukup membuat ia mempunyai pengalaman dalam mencari uang. Namun ketika ditanya apakah tidak ada lagi keinginan untuk bersekolah Tomas mengatakan masin ingin bersekolah supaya ke depan bekerja yang layak dan tidak sebagai pemulung.

Kondisi seperti yang dialami oleh R. Napitupulu, Simamora dan Tomas tentu tidak jauh berbeda dengan yang dialami oleh kebanyakan pemulung di TPA Muara Fajar. Dengan penghasilan yang tergolong rendah berkisar antara Rp.500.000 sampai 1.000 .000 perbulannya tentu tidak mencukupi semua kebutuhan apalagi biaya sekolah bagi anak-anak mereka. Bukan saja kebutuhan makan tetapi juga ketika sakit akan membutuhkan biaya ekstra untuk berobat.

Kalau dilihat dari keseluruhan pemulung di TPA Muara Fajar dengan penghasilan yang ada maka bisa dipastikan mereka tidak bisa keluar dari jerat kemiskinan dan dengan kondisi sosial ekonomi yang ada membuat para pemulung tidak memiliki akses untuk mendapatkan pekerjaan yang berpenghasilan memadai.

4. Faktor Perumahan.

Tidak bisa dipungkiri bahwa fenomena pemulung di TPA sampah di beberapa daerah di Indonesia menyuguhkan pemandangan tak biasa. Di lingkungan TPA tersebut tampak rumah-rumah gubug atau rumah bedeng. Tak jarang para pemulung membangun rumahrumah tersebut dengan materil bangunan yang tidak layak pakai seperti karton bekas sebagai dinding, lantai beralas plastik, dan atap seadanya. Maka dilihat dari kenyataan ini tentu saja fenomena sosial kemiskinan sangat menonjol pada para pemulung tersebut.

Salah satu indikator kemiskinan adalah ketidakmampuan memiliki rumah layak huni. Menurut data BPS salah satu indikator kemiskinan adalah luas lantai bangunan tempat tinggal kurang dari $8 \mathrm{~m} 2$ per orang dan jenis lantai bangunan tempat tinggal terbuat dari tanah/bambu/kayu berkualitas murahan serta jenis dinding tempat tinggal terbuat dari bambu/rumbia/kayu berkualiras rendah.

Kondisi ini juga dialami oleh para pemulung di TPA Muara Fajar Rumabi Pekanbaru. Menurut hasil wawancara penulis dengan responden terungkap bahwa sebagian besar para pemulung tidak memiliki rumah sendiri. Diantara mereka ada yang masih mengontrak rumah dan kalaupun memiliki rumah sendiri namun kebanyakan mereka menempati rumah tidak layak huni.

Br. Hutapea mengaku memiliki rumah sendiri namun masih berdinding papan dan ukurannya tergolong sangat kecil yang dihuni suami istri dan 4 orang anak. Ia mengatakan memiliki rumah ini juga membangun diatas tanah orang lain, dengan diizinkan oleh pemiliki tanah membangun sekalian menjaga tanah 
pemiliknya tersebut. Br. Hutapea juga mengatakan bahwa rumahnya juga jauh dari perkampungan masyarakat dan tidak memiliki penerangn listrik.

Br. Simamora mengungkapkan bahwa sampai saat ini ia belum memiliki rumah sendiri. Dia mengontrak rumah kecil dengan suami dan 5 orang anaknya. Tentu saja mengontrak rumah yang sangat sederhana supaya biaya kontrakannya terjangkau. Simamora mengaku mengontrak rumah perbulannya Rp. 150.000. Ini saja dirasa cukup berat karena semua kebutuhan digantungkan pada hasil pekerjaan sebagai pemulung.

Lain lagi pengakuan bapak Siahaan bahwa sebenarnya dulu dia memiliki rumah ketika bekerja sebagai sopir, namun ketika berhenti jadi sopir dan bekerja sebagai pemulung dirasakannya hidup begitu sulit karena kebutuhan keluarga yang besar dan mempunyai anak yang bersekolah 2 orang maka ia harus menjual rumahnya yang juga kecil dan sekarang hidup di rumah kontrakan dengan sanitasi lingkungan yang sangat buruk serta tidak memiliki sumber air bersih untuk kebutuhan hidup sehari-hari.

Lain lagi kisah hidup seorang pemulung, Epi yang sampai hari ini juga tidak mempunyai rumah. Dia hidup dengan ketiga anaknya serta suaminya dirumah kontrakan sempit. Pernah berusaha untuk mengajukan KPR namun tidak bisa memenuhi standar syarat-syarat kepemilikan KPR maka akhirnya kreditnya ditolak. Epi mengatakan tidak tahu sampai kapan orang susah bisa memiliki rumah layak huni. Dalam keadaan pasrah namun Epi tetap berusaha untuk memenuhi kebutuhan sehari-hari dengan menjadi pemulung di TPA.

Melihat kenyataan ini maka tidak dipungkiri lagi bahwa komunitas pemulung di TPA Muara Fajar menempati kelas sosial ekonomi paling bawah di masyarakat karena belum bisanya memenuhi kebutuhan perumahan yang layak.

\section{Faktor Pelayanan Kesehatan}

Masalah kesehatan merupakan suatu masalah yang sangat kompleks, yang saling berkaitan dengan masalah-masalah lain di luar kesehatan itu sendiri. Demikian pula untuk mengatasi maslah kesehatan masyarakat tidak hanya dilihat dari segi kesehatannya sendiri tapi harus dari segi seluruh segi yang ada pengaruhnya terhadap kesehatan tersebut (Notoatmojo, 1997).

Terwujudnya derajat kesehatan dalam masyarakat dipengaruhi oleh beberapa faktor sebagaimana yang dikemukakan oleh Hendrik L. Blum. Faktor-faktor yang dimaksud adalah faktor keturunan, faktor pelayanan kesehatan, faktor prilaku dan faktor lingkungan. Diantara faktor-faktor tersebut, faktor lingkungan merupakan faktor yang paling besar memegang peranan dalam status kesehatan masyarakat (Kusnoputranto, 1986).

Lingkungan kerja merupakan tempat yang potensial mempengaruhi kesehatan pekerja. Faktor-faktor yang mempengaruhi kesehatan pekerja antara lain faktor fisik, faktor kimia, dan faktor biologis. Lingkungan kerja ataupun jenis pekerjaan dapat menyebabkan penyakit akibat kerja (suma'mur, 1997).

Tempat Pembuangan Akhir (TPA) merupakan tempat yang berpotensi mempengaruhi kesehatan para pemulung, karena di TPA tersebut banyak tumpukan sampah dari berbagai jenis sampah yang memungkinkan bakteri dan virus brkembang. Pemulung yang ada di TPA Muara Fajar yang saat ini berjumlah tidak kurang dari 300 orang belum mendapatkan pelayanan kesehatan sebagaimana mestinya. Para pemulung yang bekerja di TPA mempunyai resiko yang sangat tinggi terhadap terjangkitnya penyakit karena mengingat jenis pekerjaan yang berkutat dengan kotoran. Kondisi lingkungan kerja pemulung berada berada di lingkungan terbuka sehingga kondisinya berhubungan langsung dengan sengatan matahari, debu dan bau dari sampah.

Pemulung di TPA Muara Fajar dalam kesehariannya bekerja kurang menjaga kebersihan dirinya antara lain tidak menggunakan sepatu boot, sarung tangan dan masker. Hal ini dapat menyebabkan timbulnya gangguan kesehatan, yang salah satunya adalah gangguan kulit. Para pemulung tidak lagi mengindahkan masalah kesehatan dengan alasan memang situasi tempat bekerja yang kotor.

Wawancara dilakukan kepada beberapa pemulung yang bertanya seputar kemana tempat berobat ketika sakit, apakah mendapatkan pelayanan yang baik, apakah mendapatkan pelayanan berobat gratis, apakah mempunyai 
kartu berobat gratis. Maka diperoleh jawaban yang beragam dari pemulung tersebut.

Br. Simamora mengaku ketika sakit baik diri sendiri, suami ataupun anak-anak maka pergi berobat ke Puskesmas terdekat. Dia mengatakan ketika berobat tidak mendapatkan pelayanan yang baik dibandingkan dengan orang-orang yang berobat dengan membayar langsung. Simamora mengatakan berobat memakai kartu berobat gratis tidak sepenuhnya dilayani dengan baik.

Lain lagi pengakuan Siahaan yang mengatakan bahwa ketika mengalami gangguan kesehatan cenderung membeli obat-obatan di toko obat karena jika berobat ke Puskesmas atau ke Rumah sakit dengan membawa kartu berobat gratis maka tidak akan mendapatkan pelayanan sebagaimana mestinya seperti lambatnya pelayanan yang didapat. Siahaan mengakui bahwa suatu saat membawa anggota keluarganya yang sakit tidak memdapatkan pelayanan yang baik. Pihak perawat atau lebih mementingkan orang-orang yang membayar langsung dibanding pakai kartu berobat gratis.

Seorang pemulung bernama Tiurna mengaku kalau anggota keluarga mengalami sakit masih berusaha untuk berobat tradisional karena tidak memiliki kartu berobat gratis dari pemerintah. Karena ketika mau mengurus kartu berobat gratis belum mempunyai KTP Pekanbaru. Makanya ketika berobat sebisanya diusahakan secara tradisional kalau tidak mampu membeli obat di toko obat.

Rata-rata para pemulung di TPA Muara Fajar mengalami kondisi yang sama ketika sakit karena selama ini belum adanya perhatian pemerintah yang serius terhadap para Pemulung di TPA tersebut. Maka kondisi sosial kesehatan komunitas pemulung merupakan salah satu indikator masalah ekonomi yang erat kaitannya dengan kemiskinan.

2. Solusi

Bagi sebagian masyarakat barangkali menganggap profesi pemulung adalah suatu pekerjaan yang hina karena berkutat dengan sampah yang bau serta menjijikkan. Namun tidak demikian dengan pekerja pemulung itu sendiri. Bagi mereka bekerja sebagai pemulung adalah pilihan yang harus dijalani semi memenuhi kebutuhan keluarga. Oleh sebab itu ketika pememrintah ingin memberi solusi terhadap permasalahan pemulung bukan saja harus membantu secara langsung terhadap pemulung itu sendiri dengan bantuan berupa uang. Tentu saja hal ini nanti juga berakibat tidak mendidik atau justru membuat pemulung pada akhirnya bermalas-malasan. Memang pada kenyataannya ketika penulis menemui para pemulung di TPA tersebut ada banyak keluhann yang disampaikan mereka berkaitan dengan harapan terhadap pemerintah untuk perbaikan nasib mereka.

Ketika penulis menanyakan apakah ada bantuan pemerintah untuk membantu memperbaiki tarap hidup mereka. Jawaban mereka cenderung sinis karena selama ini sudah sangat banyak yang datang baik individu, organisasi maupun pihak pemerintah sendiri yang datang hanya dengan memberi harapanharapan kosong. Pemulung tersebut mengatakan ada momen-momen tertentu TPA dikunjungi oleh oarng-orang yang mempunyai kepentingan baik pribadi maupun organisasi atau instansi pemerintah itu sendiri. Salah satu contoh ketika dalam masa kampanye pemilihan wakil rakyat, kepala daerah atau sekedar ingin mengekspos suatu organisasi mereka datang di TPA dan mengumbar janji-janji akan memberikan bantuan namun setelah momen tersebut selesai maka yang dijanjikan tadi tak pernah terwujud.

Pada akhirnya siapapun yang datang awalnya para pemulung cuek atau bersikap sinis karena mereka sudah cenderung muak terhadap kepentingan-kepentingan tersebut. Tidak bisa dipungkiri pula bahwa ada yang datang memberikan pelatihan-pelatihan kewirausahaan dan semacamnya namun tetap saja pada akhirnya kembali kepada pemulung itu sendiri. Tentu saja ketika ingin berwirausaha mereka akan memikirkan dari mana modal awal didapatkan. Dan ketika pertanyaan ini tidak bida terjawab maka mereka tidak punya pilihan lain kecuali meneruskan bekerja sebagai pemulung.

Di satu sisi sebenarnya keberadaan pemulung tentu tetap akan ada bahkan di seluruh kota bessar yang ada di Indonesia karena meningkatnya volume sampah dari hari ke hari terutama di perkotaan. Tentu saja keberadaan pemulung juga memberikan andil dalam membangun ekonomi perkotaan. Kenyataannya fenomena pemulung di negara-negara maju juga ada namun profesi pemulung benar-benar 
diberdayakan tidak seperti pemulung yang ada di negara Indonesia. Hal ini dikarena pada tingkat negara maju menyadari bahwa ada potensi besar yang ada pada sektor "remeh ini.

Seperti yang diketahui bahwa proses daur ukang atau recycle seperti di Jepang dan Amerika, bisa menjadi rujukan. Ribuan ton sampah baik hasil limbah rumah tangga ataupun kegiatan passal, telah dilakukan pemisahan sebelumnya. Mereka membedakan sampah plastik, sampah logam dan lainnya yang bisa didaur ulang. Selanjutnya sisa sampah yang tidak ada bernilai ekonomis di bakar dalam incenerator untuk menghasilkan tenaga listrik. Mereka sangat terorganisisr memanfaatkan limbah-limbah tersebut dengan manajemen yang tertata apik.

Sementara di Indonesia, seperti di Jakarta, Surabaya dan beberapa kota besar di Indonesia proses recycle yang berjalan justru memanfaatkan jasa para pemulung yang sama sekali tidak terorganisir dengan baik. Mereka hanya dibina oleh beberapa pengepul yang memiliki akses dengan pabrik daur ulang.

Tidak terkecuali pemulung yang ada di TPA Muara Fajar mereka juga menggantungkan hasil pulungannya setiap hari kepada pengepul yang ada di sekitar TPA tersebut. Memang sudah ada usaha dari pihak TPA untuk memberdayakan sampah menjadi pupuk dan sebagainya dan terakhir adanya rencana pemko untuk membuat gas metan dari sampah tersebut namun belum terlaksana dengan maksimal karena alasan klasik yakni terkendala dana operasional dan alat-alat yang mendukung. Maka kembali kepada fenomena yang ada bahwa para pemulung tersebut tetap akan ada selagi ada sampah yang menggunung yang dihasilkan masyarakat.

Maka dari kenyataan yang ada penulis mencoba memberikan solusi yang barangkali bisa diberikan pihak terkait terhadap fenomena ini diantaranya yakni :

1. Kalau ada yang berkepentingan terhadap pemulung baik sifatnya individu maupun organisasi jangan hanya memberikan janji kosong tetapi janji tersebut harus direalisasikan.

2. Karena pemulung sangat tergantung kepada para pengepul maka tidak ada salahnya pihak terkait memberikan bantuan modal terhadap pengepul tersebut.

3. Berkaitan dengan pengepul terjadi mata rantai dengan industri daur ulang maka bantuan juga harus diberikan kepada industri daur ulang tersebut dengan harapan industri tersebut tetap menjadi pemasok hasil dari para pemulung.

4. Karena tidak sedikit dari para pemulung tersebut yang mempunyai anak yang berseolah maka dalam hal ini tentu saja pihak terkait harus memberikan bantuan dana pendidikan terhadap anak-anak pemulung tersebut.

5. Seperti diketahui kebanyakan pemulung di TPA belum mempunyai rumah maka tidak ada salahnya pihak-pihak terkait memberikan bantuan perumahan atau memudahkan persyaratan memiliki KPR

6. Diharapkan pihak terkait datang ke TPA walaupun sekedar memberikan penyuluhan tentang kesehatan dan memberikan pengobatan gratis di lokasi TPA.

7. Bagi pihak-pihak yang berkesempatan datang ke lokasi TPA tidak ada salahnya memberikan pengertian kepada pemulung bahwa tidak ada yang salah dengan profesi pemulung namun tetap harus berusaha mencari rezeki yang halal lagi baik artinya tentu dengan pertimbangan norma sosial di masyarakat serta tetap meyakinkan pemulung betapa pentingnya menjaga kesehatan dalam hal ini salah satu penyebab datangnya penyakit adalah lingkungan yang tidak sehat.

\section{PENUTUP}

Setelah menguraikan fenomena dan menawarkan beberapa solusi akhirnya penulis berkesimpulan bahwa kondisi sosial ekonomi komunitas pemulung di TPA Muara Fajar Rumbai Pekanbaru berada pada level memprihatinkan, hal ini berdasarkan tinjauan terhadap beberapa faktor berikut :

1. Faktor Pendidikan. Rata-rata pemulung hanya menamatkan Sekolah Dasar (SD).

2. Faktor Pekerjaan.Pemulung tidak mempunyai pilihan lain karena keterbatasan akses kepada pekerjaan pada sektor formal.

3. Faktor Penghasilan. Rata-rata hasil yang didapat dari pekerjaan sebagai pemulung hanya mencukupi kebutuhan pangan sehari- 
hari dan sangat kesulitan ketika ingin memenuhi kebutuhan sandang dan papan.

4. Faktor Perumahan. Kebanyakan pemulung yang ada di TPA Muara Fajar belum memiliki rumah sendiri dan hidup dalam rumah kontrakan yang sempit dengan jumlah keluarga tergolong besar dengan jumlah anak 3 sampai 6 orang.

5. Faktor Pelayanan kesehatan. Pemulung cenderung ketika sakit tidak tidak buru-buru berobat ke Rumah Sakit atau ke Puskesmas dengan alasan keterbatasan biaya dan apabila berobat memakai kartu berobat gratis pemulung tidak mendapatkan pelayanan yang semestinya.

\section{DAFTAR PUSTAKA}

De Porter, Bobbi dan Hernacki, Mike. 1992. Quantum Learning. Membiasakan Belajar Nyaman dan Menyenangkan. Terjemahan oleh Alwiyah Abdurrahman. Bandung: Penerbit Kaifa.

Sujimat, D. Agus. 2000. Penulisan karya ilmiah. Makalah disampaikan pada pelatihan penelitian bagi guru SLTP Negeri di Kabupaten Sidoarjo tanggal 19 Oktober 2000 (Tidak diterbitkan). MKKS SLTP Negeri Kabupaten Sidoarjo

Suparno. 2000. Langkah-langkah Penulisan Artikel Ilmiah dalamSaukah, Ali dan Waseso, M.G. 2000. Menulis Artikel untuk Jurnal Ilmiah. Malang: UM Press.

UIN Suska Riau. 2000. Pedoman Penulisan Artikel Jurnal, Surabaya: Lembaga Penelitian Universitas Negeri Surabaya.

Wahab, Abdul dan Lestari, Lies Amin. 1999. Menulis Karya Ilmiah. Surabaya: Airlangga University Press.

Winardi, Gunawan. 2002. Panduan Mempersiapkan Tulisan Ilmiah. Bandung: Akatiga. 